\title{
RESIDUE DETERMINATION AND MONITORING OF THE LEVELS OF METSULFURON METHYL IN SELECTED RIVERS AT TASIK CHINI, PAHANG, MALAYSIA
}

\author{
(Penentuan Residu dan Pemantauan Metsulfuron Metil di Sungai Terpilih di Tasik Chini, \\ Pahang, Malaysia) \\ Khairiatul Mardiana Jansar* and Ismail Bin Sahid \\ School of Environment and Natural Resource Sciences, \\ Faculty of Science and Technology, \\ Universiti Kebangsaan Malaysia, 43600 UKM Bangi, Selangor, Malaysia \\ *Corresponding author: mardiana@ukm.edu.my
}

Received: 9 December 2014; Accepted: 16 October 2015

\begin{abstract}
The levels of metsulfuron methyl (methyl 2-(4-methoxy-6-methyl-1,3,5-trazine-2-ylcarbamoylsulfamoyl) benzoate (IUPAC) (MSM) and its metabolite IN-A4098 (4-methoxy-6-methyl-1,3,5-triazin-2-amine (AMMT) were determined from surface water samples of six rivers located at Tasik Chini, Pahang, Malaysia. The optimization analytical method was developed for the determination of the MSM herbicide and its metabolite, AMMT in surface water up to $0.05 \mathrm{ng} / \mathrm{ml}$ with good linearity in the calibration range $0.1-10 \mathrm{ng} / \mathrm{ml}$. The procedure involves a clean-up process using the IST ISOLUTE ENV ${ }^{+}$solid phase extraction (SPE) method and the pesticide level are determined using the HPLC with variable wavelength detector (VWD) and $81-105 \%$ recovery. The MSM compound represents one of main herbicides used in the Tasik Chini oil palm plantation. The method enables study to be made of the herbicide and its transformation products through simultaneous detection and quantification. In the field study levels of MSM in the surface water ranged from undetectable to $0.1378 \mathrm{ng} / \mathrm{ml}$ from the first season to forth season, while levels of the metabolite, AMMT ranged from undetectable to $1.473 \mathrm{ng} / \mathrm{ml}$. The variation of the MSM and AMMT levels depended directly on the time of the pesticide application and the season.
\end{abstract}

Keywords: metsulfuron methyl, metabolite, solid phase extraction, Tasik Chini

\begin{abstract}
Abstrak
Tahap pencemaran metsulfuron metil (metil 2-(4-metoksi-6-metil-1,3,5-triazin-2-ilkarbamoilsulfamoil) benzoat (IUPAC) (MSM) dan metabolit IN-A4098 (4-metoksi-6-metil-1,3,5-triazin-2-amina (AMMT) telah ditentukan daripada sampel air permukaan daripada enam batang sungai yang terletak di Tasik Chini, Pahang, Malaysia. Pengoptimuman kaedah analisis telah dibuat untuk menentukan kandungan herbisid MSM dan metabolitnya, AMMT dalam air permukaan dengan kepekatan minimum adalah $0.05 \mathrm{ng} / \mathrm{ml}$ dan julat kalibrasi adalah $0.1-10 \mathrm{ng} / \mathrm{ml}$. Prosedur ini melibatkan satu proses pengekstrakkan menggunakan IST ISOLUTE ENV ${ }^{+}$kaedah pengekstrakan fasa pepejal (SPE) dan tahap herbisid ditentukan menggunakan HPLC dengan pengesan gelombang pelbagai (VWD) pada tahap perolehan semula adalah $81-105 \%$. Sebatian MSM merupakan salah satu daripada herbisid utama yang digunakan dalam ladang kelapa sawit Tasik Chini. Kaedah ini membolehkan herbisid dan metabolitnya dikesan dan dianalisis serentak. Di peringkat kajian lapangan, julat bacaan MSM dalam air permukaan adalah dari tidak dapat dikesan sehingga $0.1378 \mathrm{ng} / \mathrm{ml}$ dari musim pertama hingga musim keempat, manakala tahap pencemaran AMMT, yakni metabolitnya adalah dalam julat yang tidak dapat dikesan hingga $1.473 \mathrm{ng} / \mathrm{ml}$. Tahap pencemaran MSM dan AMMT bergantung secara langsung kepada masa penyemburan herbisid dan musim kawasan tersebut.
\end{abstract}

Kata kunci: metsulfuron metil, metabolit, pengekstrakkan fasa pepejal, Tasik Chini 


\section{Khairiatul Mardiana \& Ismail: RESIDUE DETERMINATION AND MONITORING OF THE LEVELS OF METSULFURON METHYL IN SELECTED RIVERS AT TASIK CHINI, PAHANG, MALAYSIA}

\section{Introduction}

Sulfonylurea herbicides are widely used in agriculture by reason of their low application rates, good crop selectivity and very low animal toxicity [1]. One of the common sulfonylurea herbicides used in oil palm plantations is metsulfuron methyl (MSM) which is often sprayed with glyphosate. MSM is particularly effective on some annual and perennial broad-leaved species and can be degraded by microbes into 4-methoxy-6-methyl-1,3,5-triazin-2amine (AMMT). It is a selective, translocated herbicide that is mainly absorbed through leaves. Its main uses are for broad-leaved weed control in oil palm plantations in Malaysia, as a tank mix with glyphosate for pre-plant weed control and for the control of perennial weeds. Metsulfuron methyl acts on the plants, ALS enzyme (not present in animals) and this is the main reason for its low toxicity to mammals, birds and fish [2].

Pollution of surface water with metsulfuron methyl can occur when the pesticide is sprayed during the rainy season, at hilly areas, consisting of impermeable soil such as clay soil, or soil with low organic content and high $\mathrm{pH}[3,4]$. The indigenous tribes in Tasik Chini are still consuming the surface water of the lake for bathing and fishing, and some of the populations are using groundwater for their daily needs. Thus, it is important to monitor the level of pesticide in the lake (Tasik Chini) before it endangers human and aquatic lives. Contamination of groundwater can occur if the soil is sandy loam type because MSM is highly soluble in water, with $\log \mathrm{K}_{\mathrm{ow}}$ at 1.8 and 0.018 for $\mathrm{pH} 5$ and $\mathrm{pH} 7$ respectively (water solubility of MSM pesticide is $\mathrm{pH}$ dependent) [5]. It is not hazardous to the environment as its usage rate is low, it has low toxicity and degradation in the field is rapid. However, there are studies that contradict its low toxicity effects, whereby concerns arise with regard to the possibility of environmental contamination, mainly regarding the leaching potential into the ground water system [6,7]. Besides, due to its high solubility in water there is a need to monitor and compare the level of metsulfuron methyl sprayed in the oil palm plantation area at different seasons (rainy and dry). No specific maximum residue limit (MRL) has been established; therefore a default MRL of $0.1 \mathrm{mg} / \mathrm{L}$ applies to food [3]. Conversion of the sulphonylurea herbicide group has been studied [8] and initial cleavage of the sulphonylurea bridge has been identified as the main transformation reaction. The primary degradation occurs with $\mathrm{DT}_{50}$ in 81-148 days [8], whereby, the products subsequent from the cleavage (of metsulfuron-methyl) is include, 4-methoxy-6-methyl-1,3,5-triazin-2-amine (AMMT).

Recent years, many alternative techniques have been explored and established, these include using capillary electrophoresis, gas chromatography and liquid chromatography $[10,11,12,13]$ to extract metsulfuron methyl and its metabolite. Solid phase extraction (SPE) is the preferred method for environmental samples instead of liquidliquid extraction due to its simple operation. A few studies on SPE type comparison have been conducted to select the SPE type that is suitable for sulfonylurea herbicide extraction. For the present study IST ISOLUTE ENV ${ }^{+}$ cartridge was used. The quantification of extracted MSM and AMMT was detected by a high performance liquid chromatograph (HPLC) equipped with a variable wavelength detector. Liquid chromatography procedure used as the routine method in the laboratory was adapted from previous research [15].

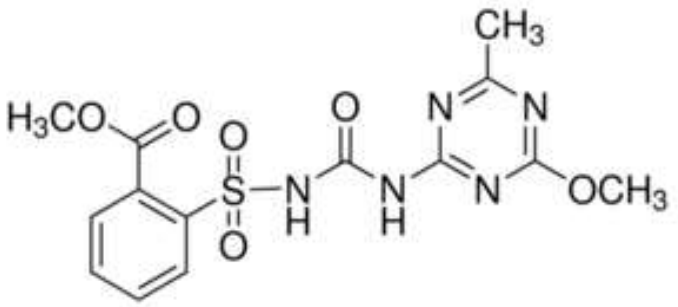

(a)<smiles>COc1nc(C)nc(N)n1</smiles>

(b)

Figure 1. Molecular structure of (a) Metsulfuron methyl (MSM) and (b) 4-methoxy-6-methyl-1,3,5-triazin-2-amine (AMMT) 


\section{Study Area}

\section{Materials and Methods}

Tasik Chini is located at the south eastern region of the state of Pahang, Malaysia and approximately $100 \mathrm{~km}$ from Kuantan, the capital of Pahang. The Tasik Chini lake system lies between $3^{\circ} 22^{\prime} 30^{\prime \prime}$ to $3^{\circ} 28^{\prime} 00^{\prime \prime} \mathrm{N}$ and $102^{\circ} 52^{\prime} 40^{\prime \prime}$ to $102^{\circ} 58^{\prime} 10^{\prime \prime} \mathrm{E}$ and comprises 12 open water bodies that are referred to as "laut" by the local people. There are a few groups of the indigenous Jakun tribe that live around the lake. Tasik Chini is the second largest natural freshwater lake in Malaysia (after Tasik Bera). It covers 202 hectares of open water and 700 hectares of riparian, peat, hill and lowland Dipterocarp forests. There are three hilly areas surrounding the lake, namely Bukit Ketaya (209 m) in the southeast, Bukit Tebakang $(210 \mathrm{~m})$ at the north and Bukit Chini $(641 \mathrm{~m})$ located southwest. The study area has a humid tropical climate with two monsoon seasons, characterized by the following bimodal pattern: southwest and northeast monsoons bringing rainfall which varies from 1488 to $3071 \mathrm{~mm}$ annually. The mean annual rainfall is $2500 \mathrm{~mm}$ and the temperature range is from 21 to $32{ }^{\circ} \mathrm{C}$. The lake drains northeasterly into the Pahang River through the Chini River, which flows for $4.8 \mathrm{~km}$ before it reaches the Pahang River. Sampling sites were selected according to land use and are shown in Figure 2.

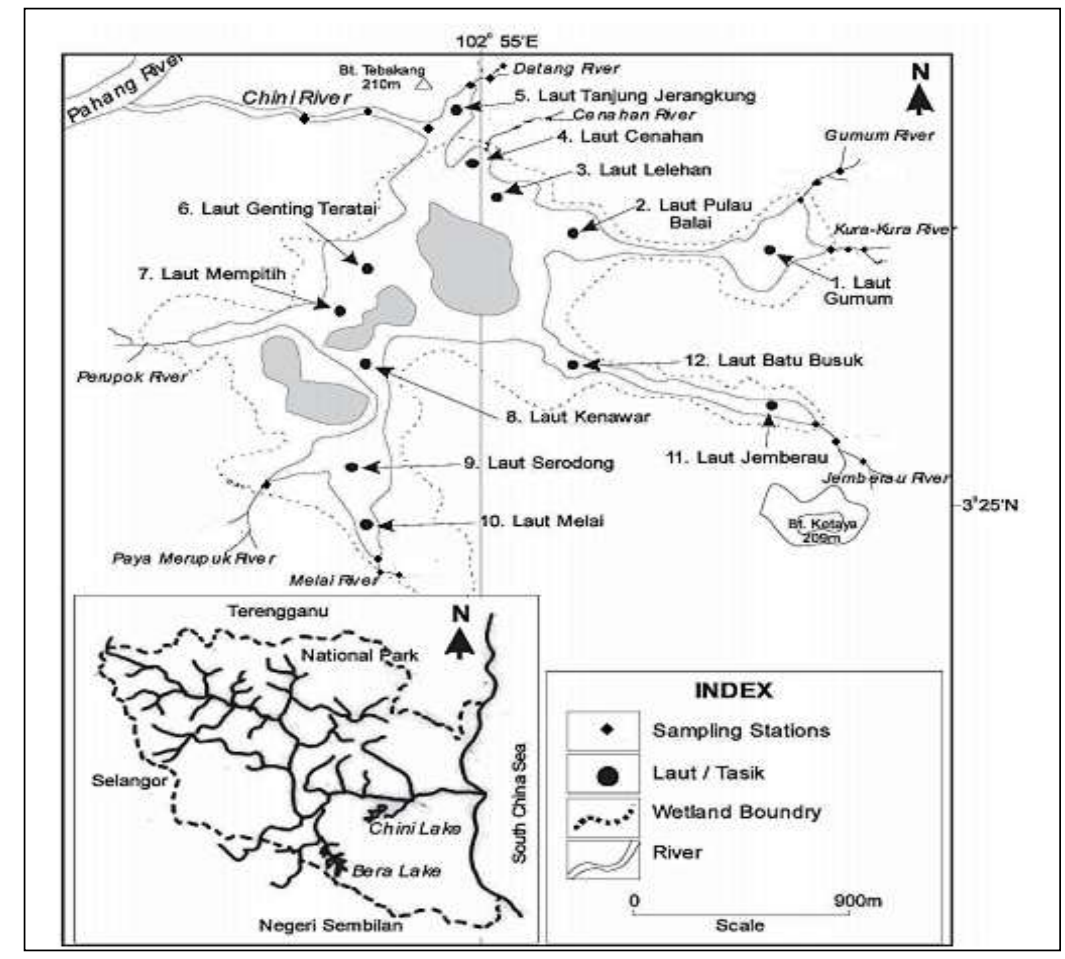

Figure 2. Map of the region: studied area and sampling sites

\section{Sampling}

Application of 150 gram/hectare MSM was applied on 15/12/2011, 14/03/2012, 13/06/2012 and 12/09/2012 to an individual oil palm plantation area near (20 meters) Sungai Jemberau (with the permission of the oil palm plantation owner and other pesticide applications were controlled). Herbicide application dates were decided by the researcher. The method of application involved spraying of the formulation using a backpack sprayer. Samples were taken one day after the MSM spraying and sampling details are as shown in Table 1 and Table 2 respectively. Water samples were taken from each sampling sites in accordance to standard methodology [12]. Samples were stored at glass containers in $\mathrm{pH} 5-6$ (adjusted) for not more than one week at $-4^{\circ} \mathrm{C}$ prior to analyses. 


\section{Khairiatul Mardiana \& Ismail: RESIDUE DETERMINATION AND MONITORING OF THE LEVELS OF METSULFURON METHYL IN SELECTED RIVERS AT TASIK CHINI, PAHANG, MALAYSIA}

\section{Reagents}

All reagents and solvents used in the study were of HPLC grade. The MSM was purchased from Sigma Aldrich and the AMMT was purchased from Dr. Ehrenstorfer GmbH. The ultra-pure water was produced using of a sartorius water purification system (Sartorius, Germany). All calibration stock solutions of MSM and AMMT (500 mg/L) were prepared in methanol and stored at $4{ }^{\circ} \mathrm{C}$ for not more than six months. Working standards were prepared in methanol and used by the addition of the standard to samples for the recovery test and stored at $4{ }^{\circ} \mathrm{C}$ for less than one week. Each sample was analysed three times. Good linearity was obtained for the every signal for MSM and AMMT if no interfering pollutant was present.

Table 1. Identification of sampling time

\begin{tabular}{lll}
\hline Sampling Season & Sampling date & Description \\
\hline M1 & $16 / 12 / 2011$ & Rainy season \\
M2 & $15 / 03 / 2012$ & Rainy season \\
M3 & $14 / 06 / 2012$ & Regular raining \\
M4 & $13 / 09 / 2012$ & Dry season \\
\hline
\end{tabular}

Table 2. Identification of samples taken from study area

\begin{tabular}{lll}
\hline Sampling & Location & Description \\
\hline D1 & Sungai Datang downstream & Forest area, fishing area \\
D2 & Sungai Datang middle & Forest area, fishing area \\
D3 & Sungai Datang up stream & Forest area, fishing area, oil palm plantation area \\
C1 & Sungai Chini downstream & Recreation area, boating \\
C2 & Sungai Chini middle & Recreation area, boating \\
C3 & Sungai Chini up stream & Recreation area, boating \\
G1 & Sungai Gumum downstream & Indigenous tribe settlement \\
G2 & Sungai Gumum middle & Indigenous tribe settlement \\
G3 & Sungai Gumum up stream & Indigenous tribe settlement \\
K1 & Sungai Kura-kura downstream & Indigenous tribe settlement \\
K2 & Sungai Kura-kura middle & Indigenous tribe settlement \\
K3 & Sungai Kura-kura up stream & Indigenous tribe settlement \\
J1 & Sungai Jemberau downstream & Oil palm plantation area \\
J2 & Sungai Jemberau middle & Oil palm plantation area \\
J3 & Sungai Jemberau up stream & Oil palm plantation area \\
L1 & Sungai Melai downstream & Mining and logging activities area, Indigenous people settlement \\
L2 & Sungai Melai middle & Mining and logging activities area \\
L3 & Sungai Melai up stream & Mining and logging activities area \\
\hline
\end{tabular}

\section{Instrumentation and chromatographic conditions}

Liquid chromatographic analysis was performed with an Agilent 1220 Infinity LC System (Agilent, US) equipped with a dual plunger in series pump with proprietary servo-controlled variable stroke drive, an automatic injector, 
and a variable wavelength detector (VWD). The Agilent 1220 instrument was controlled by computer (OpenLab Chemstation Edition software); data from the VWD was collected and evaluated by use of the same station after transfer via an analog-to-digital converter.

Separations were performed on a $150 \mathrm{~mm}, 4.6$ x 150, $3.5 \mu \mathrm{m}$, Zorbax Eclipse XDB-C18 column (Agilent, USA), $3.5 \mu \mathrm{m}$ internal diameter packed with high purity silica; The mobile phase was (A) methanol: acetonitrile: acetic acid $=50: 50: 0.01 \%$ and (B) $0.005 \mathrm{M}$ phosphate buffers: acetic acid $=100: 0.01 \%$ with adjusted $\mathrm{pH}$ to 2.5 . Separation compound was achieved in a gradient condition, $15 \%$ B linear for 1.5 minutes, increased to $60 \%$ B in 5.5 minutes, linear $60 \%$ B for 8 minutes, then returned to $15 \%$ B in 3 minutes. The column temperature was controlled at $40^{\circ} \mathrm{C}$ (sharpness of the compound peaks are better compared to uncontrolled temperature) and the volume of the sample injected was $20 \mu \mathrm{L}$. Variable wavelength detection, $200 \mathrm{~nm}$, was used to monitor the products. A post-run period of 5 minutes was used for stabilisation. A total of 25 minutes of analysis was needed.

\section{Sample Preparation and Clean-up Process}

Water samples ( 1 liter) were collected in amber glass bottles and stored at $-4^{\circ} \mathrm{C}$ for a short term storage. After thawing, samples were filtered through a $0.45-\mu \mathrm{m}$ nylon membrane filter and the filtrate was adjusted to $\mathrm{pH} 5-6$ by addition of dilute hydrochloric acid $(0.136 \mathrm{M})$. Samples were placed in ultrasonic bath for 15 minutes before the clean-up process. The targeted herbicide and its metabolite (MSM AND AMMT) were extracted by pulling the sample through a reverse-phase solid phase extraction (SPE) cartridge $\left(\mathrm{ENV}^{+}\right.$cartridge). Before pulling the sample through the cartridge, the cartridge was rinsed with $3 \mathrm{ml}$ of acetonitrile and $3 \mathrm{ml}$ of water to reduce residual acidity within the cartridge, and then dried to remove any residual water. The analytes were eluted off the SPE cartridge using $8 \mathrm{ml}$ of methanol. The resulting elute was evaporated near to dryness exactly at $1 \mathrm{ml}$. This final extract was filtered through a $0.20 \mu \mathrm{m}$ membrane filter, and submitted for analysis.

\section{Results and Discussion}

The method optimised for detection of MSM and AMMT in water samples showed the following parameters: level of detection for water sample was $5 \mu \mathrm{g} / \mathrm{L}$ for MSM and $1 \mu \mathrm{g} / \mathrm{L}$ for AMMT with a good linearity in the standard addition calibration range $1-50 \mu \mathrm{g} / \mathrm{L}\left(\mathrm{r}^{2}=0.998-0.999\right)$. Retention time for MSM was 3.176 minutes and for AMMT 10.721 minutes (Figure 3). Recovery rates of $83-110 \%$ were obtained for MSM and AMMT in water of pH 5.26. Figure 6 shows the recovery of $3 \mathrm{mg} / \mathrm{L}$ obtained for the $\mathrm{pH}$ range of $2.38-10.27$. Using the gradient method, it was possible to perform simultaneous analysis for the herbicide (MSM) and its metabolites (AMMT). Thus, using the methods presented, it was possible to screen both MSM and AMMT simultaneously.

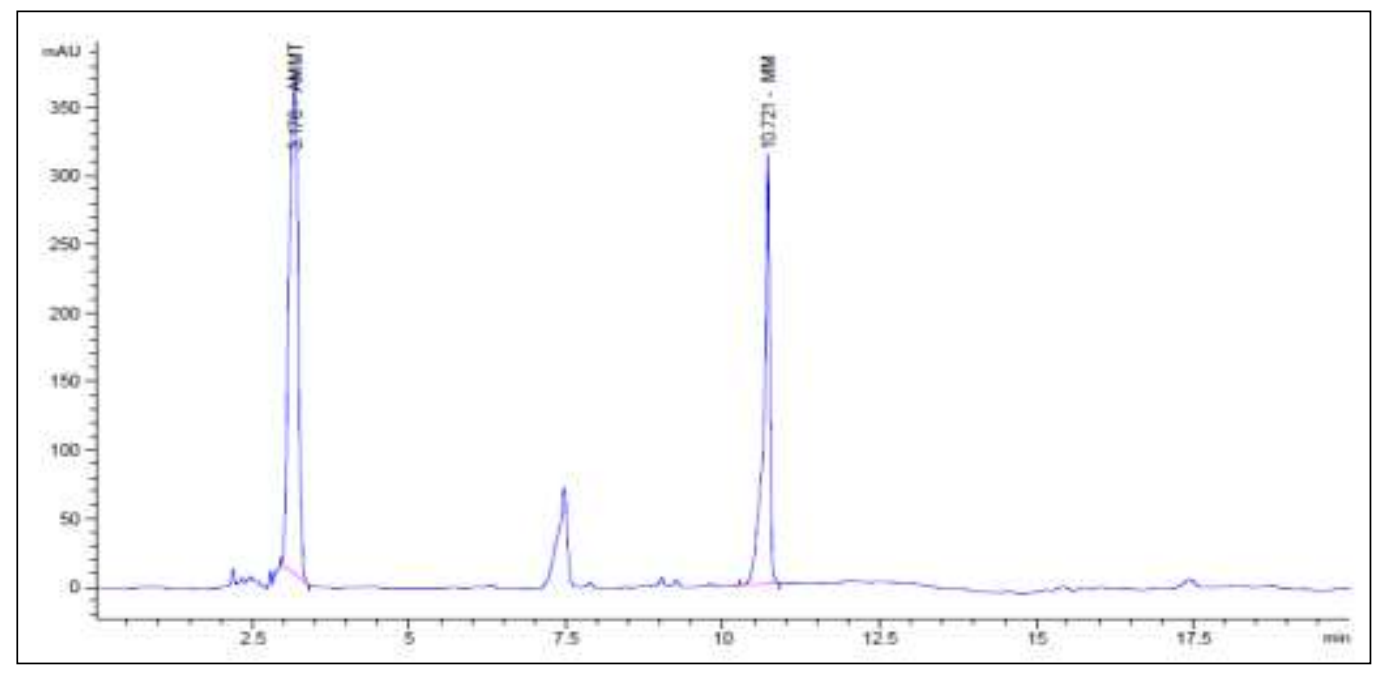

Figure 3. Gradient method: HPLC profile of spiked MSM and AMMT. Chromatogram has been corrected for baseline drift (overlay sample chromatogram on blank chromatogram) 


\section{Khairiatul Mardiana \& Ismail: RESIDUE DETERMINATION AND MONITORING OF THE LEVELS OF METSULFURON METHYL IN SELECTED RIVERS AT TASIK CHINI, PAHANG, MALAYSIA}

In the present study, samples were collected four times from each of the 18 stations at six selected rivers during the wet and dry seasons. M1 and M2 represented the rainy season, with monthly average rainfall of $300 \mathrm{~mm}$ to $400 \mathrm{~mm}$, meanwhile M4 represented the dry season, with a monthly average rainfall of $50 \mathrm{~mm}$ to $150 \mathrm{~mm}$, and M3 the regular season, with a monthly average rainfall of $150 \mathrm{~mm}$ to $300 \mathrm{~mm}$. The result obtained from water monitoring for MSM and AMMT from the sampling is provided in Figure 4 and Table 3. MSM concentration in the water ranged from undetectable to $604.4 \mu \mathrm{g} / \mathrm{L}$ (Figure 5). The amount of AMMT prevent in several stations and seasons shown in Table 3. A significant increase of the MSM concentration in the water was observed in the vary season (M1 and M2) in most of the rivers. The release of MSM can be associated with surface runoff from the oil palm plantation area and with soil exposure to MSM. These results showed the drift of MSM due to precipitation and related leaching in relation to its high solubility in water and its binding ability to the soil particles which drifted by the runoff [9]. In the present study, rain events played an important role transporting the MSM present in the soil towards the water stream through the mechanisms of dilution or drift of surface material by runoff. For Sungai Jemberau (J1, J2 and J3) the concentration increased from downstream to upstream possibly due to the location of the oil palm plantation area. A different patent occurred for Sungai Gumum (G1, G2 and G3) where the concentration decreased from downstream to upstream, perhaps due to the reduction of oil palm plantation area at the upstream area. Referring to the amount of AMMT in the water, there was no trend observed in the water bodies during the monitoring period and AMMT was found mainly during the dry season at low concentrations < $0.15 \mathrm{mg} / \mathrm{L}$.

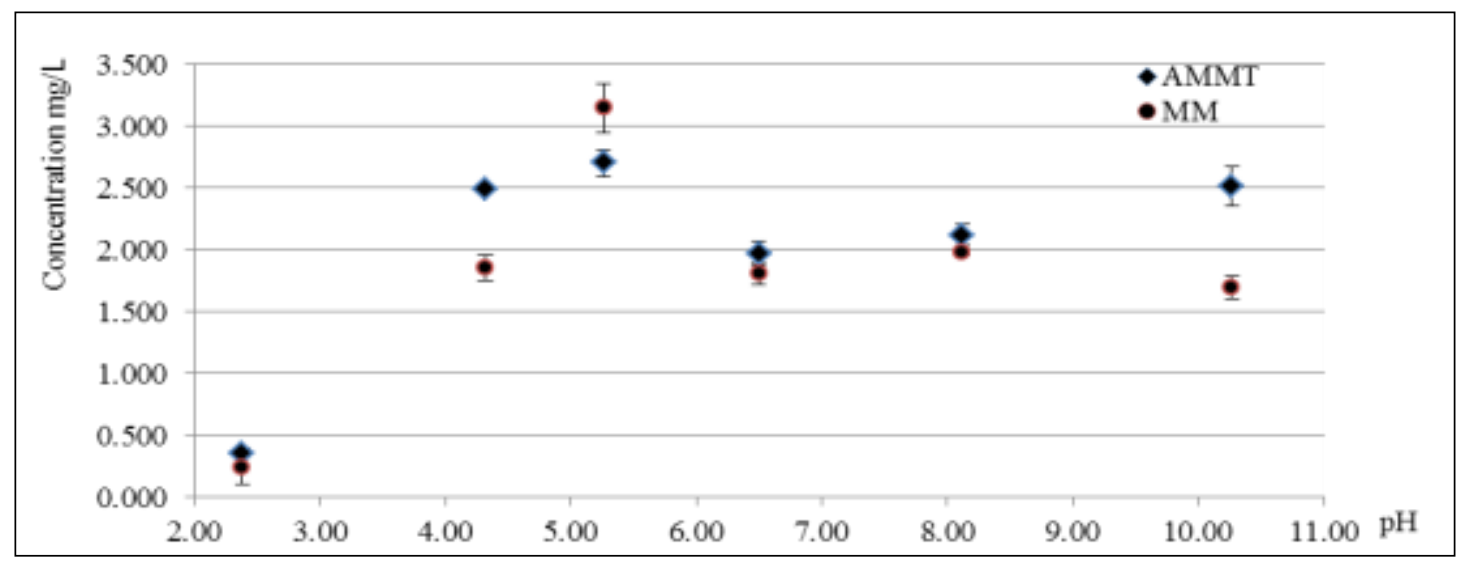

Figure 4. Recovery result of $3 \mathrm{mg} / \mathrm{L}$ for the $\mathrm{pH}$ range of $2.38-10.27$

Table 3. AMMT concentration

\begin{tabular}{lll}
\hline Sampling & Sampling place & Concentration $(\mathbf{m g} / \mathbf{L})$ \\
\hline Season 1 & K3 & 0.0191 \\
Season 2 & D1 & 0.0510 \\
Season 3 & Every sampling point is not detected \\
Season 4 & CH2 & 0.0220 \\
& D1 & 0.1390 \\
& D2 & 0.0575 \\
& K1 & 0.0472 \\
& K2 & 0.1238 \\
& K3 & 0.0381 \\
\hline
\end{tabular}




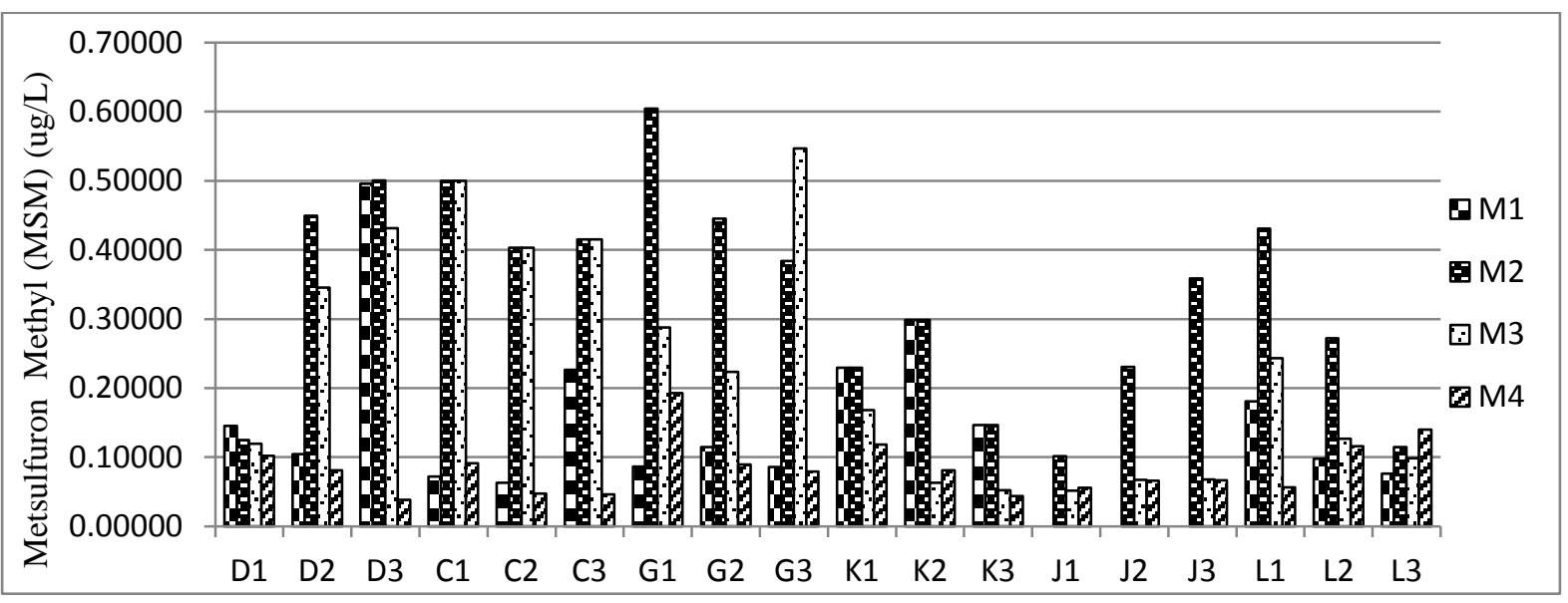

Figure 5. MSM concentration in water

\section{Conclusion}

The inclusion of the study of metabolites in monitoring programs and in experimental studies is mandatory. The optimized method used showed an adequate sensitivity for the detection of MSM and AMMT in water samples by a simple procedure. Concerning the levels of MSM detected in the water samples, there was no direct relationship observed between MSM application time and its detection in water. However, the rain events cause a rise in MSM concentration in the water. Finally, the contribution of this preliminary study is disclosed because there is little unpublished information in this region regarding pesticides application. Further studies for pesticide modeling on a monthly basis will be a useful tool for estimation of application rates.

\section{Acknowledgement}

The authors wish to thank the Ministry of Science, Technology and Innovation (MOSTI) for the grant (06-01-02SF0827) to fund this project; Pusat Penyelidikan Tasik Chini and Faculty of Science and Technology, UKM for the research facilities.

\section{References}

1. Beyer, E .M., Duffy, M. J., Hay, J. V. and Schlueter, D. D. (1988). Sulfonylureas. In: Kearney, P.C., and Kaufman, D.D. (Eds.), Herbicides. Chemistry, Degradation and Mode of Action, Dekker, New York.

2. Ray, T. B. (1984). Site of action of chlorsulfuron: inhibition of valine and isoleucine biosynthesis in plants. Plant Physiology, 75, $827-831$.

3. Health Canada Pest Management Regulatory Agency (2008). Re-evaluation Decision. Metsulfuron Methyl. Ontario: Minister of Public Works and Government Services Canada.

4. Abdullah, A. R, Saraswathy, S. and Norhayati, M. T. (2001). Adsorption-desorption and mobility of metsulfuron methyl in selected Malaysian agricultural soils. Bulletin of Environmental Contamination and Toxicology 66: $762-769$.

5. Brown, H. M., Gaddamidi, V. and Lee, P. W. (1998). Sulfonylureas. In: Hutsons, D. H., and Roberts, T. (Eds.), Metabolic Pathways of Agrochemicals: Herbicides and plant growth regulators. The Royal Science of Chemistry, Cambridge.

6. Kjaer, C. M. Strandberg, and Erlandsen, M. (2006). Effects on hawthorn the year after simulated spray drift. Chemosphere. 63(5): $853-859$.

7. Li, Z. J., Xu, J. M., Muhammad, A. and Ma, G. R. (2005). Effect of bound residues of Metsulfuron-methyl in soil on rice growth. Chemosphere. 58: $1177-1183$. 
8. Berger, B. M. and Wolfe, N. L. (1996). Hydrolysis and biodegradation of sulfonylurea herbicides in aqueous buffers and anaerobic water-sediment systems: assessing fate pathways using molecular descriptors. Environmental Toxicology Chemistry, 15:1500 - 1507.

9. Wang, H., Yang, F., Liu, G., Lei, Y. and Ye, Q. (2011). Monitoring of metsulfuron-methyl and its residues in an artificial pond. Environmental Monitoring Assessment, 174(1-4):597 - 604.

10. Singh S. B. and Paul, R. (2011). Gas chromatographic method for residue analysis of metsulfuron methyl from soil. Bulletin of Environmental Contamination and Toxicology, 86(2):149 - 151.

11. Bossi, R., Seiden, P., Andersen, S. M., Jacobsen, C. S. and Streibig, J. C. (1999). Analysis of metsulfuronmethyl in soil by liquid chromatography/Tandem Mass Spectrometry. Application to a field dissipation study. Agricultural Food Chemistry, 47(10):4462 - 4468.

12. National Council for Air and Stream Improvement, Inc. (NCASI) (2007). Hexazinone, Imazapyr, Metsulfuron Methyl, and Sulfometuron Methyl in Water by Solid Phase Extraction and HPLC/UV. NCASI Methods Manual. Research Triangle Park, NC: National Council for Air and Stream Improvement, Inc.

13. Shobha S. (2008). Persistence of metsulfuron-methyl in wheat crop and soil. Environmental Monitoring and Assessment, 147:463-469.

14. Halimah, M. Tan, Y. A. and Ismail, B. S. (2007). New and rapid method of analysis of metsufuron methyl in water sample. Proceedings of Product Development and Nutrition Conference: PIPOC 2007 International Palm Oil Congress: Palm Oil: Empowering Change. Kuala Lumpur (Malaysia), 26 - 30 Aug, 2007: pp 176.

15. Juhler, R., Sørensen, S. and Larsen, L. (2001). Analysing transformation products of herbicide residues in environmental samples. Water Research, 35(6), 1371-1378. 